\title{
New Products of Defense Secretion in South East Asian Whip Scorpions (Arachnida: Uropygi: Thelyphonida)
}

Joachim Haupt ${ }^{\mathrm{a},{ }^{*}}$ and Frank Müller ${ }^{\mathrm{b}}$

a Institute of Ecology, Technical University Berlin (FR 1-1), Franklinstr. 28/29,

D-10587 Berlin, Germany. Fax: 00493031473177. E-mail: hptjeiic@mailbox.tu-berlin.de

b Institute of Biology, Applied Zoology, Free University Berlin, Haderslebener Str. 9,

D-12263 Berlin, Germany

* Author for correspondence and reprint requests

Z. Naturforsch. 59c, 579-581 (2004); received April 28/May 19, 2004

Secretion products from the opisthosomal defense gland of south east Asian whip scorpions were identified for the first time by gas-chromatography and mass-spectrometry. Specimens of the genera Hypoctonus, Typopeltis and Ginosigma were tested. While some ingredients are present in large concentrations, others are possibly only side products and may be synthesized more incidentally. For this reason no important functional role is attributed to them. There are considerable individual differences concerning the concentrations of various ingredients. While the secretion products of most species of the genus Typopeltis - similar to Mastigoproctus - are characterized by acetic and octanoic acid in large concentrations, the secretion product of Hypoctonus siamensis provides octanoic acid only in a very low concentration but it is characterized by hexyl acetate.

Key words: Uropygi, Defense Secretion, Analysis

\section{Introduction}

The variety of secretion products in whip scorpions reaches from pure acetic and octanoic (caprylic) acid (Eisner et al., 1961) in the American Mastigoproctus giganteus and in Japanese whip scorpions (Yogi and Haupt, 1977; Itokawa et al., $1981,1985)$ to the addition of ketones in the Chinese species Typopeltis guangxiensis (Haupt et al., 1988; Haupt, 2000), alcohols and esters (Haupt et al., 1993). Here, further ingredients are reported from additonal genera and species living in south east Asia. Their importance is discussed in relation to practical implications for these species. Another important point is apparently the way of acquisition of secretion products, which deserves intensive discussion.

\section{Material and Methods}

The following species of Uropygi from Thailand were used for the current study: Hypoctonus siamensis Haupt, 1996 (12 samples from the vicinity of Chiang Mai), Typopeltis tarnanii Pocock, 1902 (2 samples from the vicinity of Chiang Mai), $T$. soidaoensis Haupt, 1996 (4 samples from Chanthaburi province) and Ginosigma schimkewitschi (Tarnani, 1894) (17 samples from Sakaerat Envi- ronmental Experiment Station, Nakhon Ratchasima).

Secretion products from the opisthosomal glands were collected during the process of spraying. For this purpose sample vials (cap with styrene/butadiene) with clean cotton and methanol as solvent were held over the whip. The methanol contained $0.1 \mu \mathrm{g} / \mu \mathrm{l}$ tridecane in order to detect the concentration of ingredients more easily. From such vials the secretion product could easily be transferred into the gas chromatograph for further processing: $4^{\prime}$ at $40^{\circ} \mathrm{C}$, then $10^{\prime}$ with rising temperature to $280{ }^{\circ} \mathrm{C}$; injection temperature $240{ }^{\circ} \mathrm{C}$; $1 \mu \mathrm{l}$ probe; column DB5 $(0.32 \mathrm{~mm} \times 30 \mathrm{~m})$. In some cases a SPME method (without solvent) was used in order to avoid masking of substances in lower concentration.

No standards were used, but all substances could be identified by comparison with literature data (NIST and own library). The determination of concentrations is based on quotients to the internal standard (100 ng).

\section{Results}

According to the present results in any case acetic acid is the main component. It occurs in all Typopeltis species studied. In Hypoctonus sia- 
Table I. Results of the analysis of ingredients after injection of the secretion product with methanol as solvent (in \%).

\begin{tabular}{|c|c|c|c|c|c|c|c|c|c|}
\hline $\begin{array}{l}\text { Species/ } \\
\text { Ingredients }\end{array}$ & Hexanol & $\begin{array}{l}\text { Hexanoic } \\
\text { acid }\end{array}$ & $\begin{array}{l}\text { Hexyl } \\
\text { acetate }\end{array}$ & $\begin{array}{l}\text { Heptanoic } \\
\text { acid }\end{array}$ & $\begin{array}{l}\text { Heptyl } \\
\text { acetate }\end{array}$ & $\begin{array}{l}\text { Octanoic } \\
\text { acid }\end{array}$ & $\begin{array}{l}\text { Octyl } \\
\text { acetate }\end{array}$ & $\begin{array}{l}\text { Hexyl } \\
\text { hexanoate }\end{array}$ & $\begin{array}{l}\text { Octadecyl } \\
\text { acetate }\end{array}$ \\
\hline $\begin{array}{l}\text { Hypoctonus } \\
\text { siamensis }\end{array}$ & $\begin{array}{l}1.6( \pm 0.8) \\
\mathrm{n}=12\end{array}$ & $\begin{array}{l}10.7( \pm 5.1) \\
\mathrm{n}=12\end{array}$ & $\begin{array}{l}56.2( \pm 11.9) \\
\mathrm{n}=12\end{array}$ & $\begin{array}{l}0.8( \pm 0.8) \\
\mathrm{n}=2\end{array}$ & $\begin{array}{l}1.6( \pm 0.4) \\
\mathrm{n}=2\end{array}$ & $\begin{array}{l}3.2( \pm 2.6) \\
\mathrm{n}=3\end{array}$ & $\begin{array}{l}6.1( \pm 7.9) \\
\mathrm{n}=3\end{array}$ & $\begin{array}{l}5.9( \pm 2.9) \\
\mathrm{n}=12\end{array}$ & $\begin{array}{l}12.2( \pm 5.8) \\
\mathrm{n}=12\end{array}$ \\
\hline $\begin{array}{l}\text { Typopeltis } \\
\text { soidaoensis }\end{array}$ & - & $\begin{array}{l}40.8( \pm 11.0) \\
\mathrm{n}=4\end{array}$ & - & $\begin{array}{l}2.2( \pm 0.5) \\
\mathrm{n}=4\end{array}$ & - & $\begin{array}{l}54.2( \pm 10.5) \\
\mathrm{n}=4\end{array}$ & - & - & $\begin{array}{l}1.7( \pm 0.8) \\
\mathrm{n}=4\end{array}$ \\
\hline $\begin{array}{l}\text { Typopeltis } \\
\text { tarnanii }\end{array}$ & - & $\begin{array}{l}0.04 \\
\mathrm{n}=1\end{array}$ & - & $\begin{array}{l}1.7 \\
\mathrm{n}=1\end{array}$ & - & $\begin{array}{l}92.7( \pm 5.7) \\
\mathrm{n}=2\end{array}$ & - & - & $\begin{array}{l}6.05( \pm 7.0) \\
\mathrm{n}=2\end{array}$ \\
\hline $\begin{array}{l}\text { Ginosigma } \\
\text { schimkewitschi }\end{array}$ & - & - & - & $\begin{array}{l}0.19( \pm 0.24) \\
\mathrm{n}=9\end{array}$ & - & $\begin{array}{l}90.2( \pm 5.2) \\
\mathrm{n}=17\end{array}$ & - & - & $\begin{array}{l}8.5( \pm 3.8) \\
\mathrm{n}=17\end{array}$ \\
\hline
\end{tabular}

mensis it makes up 36.7\% (SPME, $\mathrm{n}=1)$ and in Ginosigma schimkewitschi 39.6\% (SPME, $\mathrm{n}=1$ ). In Ginosigma schimkewitschi low concentrations of propionic and valeric acid were detected $(0.8 \%$ and $0.03 \%$, respectively), in Hypoctonus siamensis propionic acid was found $(0.3 \%)$.

Further ingredients were detected in samples containing methanol as solvent (Table I): Besides acetic acid large concentrations of octanoic (caprylic) acid were found in Typopeltis species and in Ginosigma schimkewitschi. Other substances are generally present only in rather low concentrations (except for hexanoic acid in Typopeltis soidaoensis and hexyl acetate in Hypoctonus siamensis).

\section{Discussion}

Thailand is the home of at least three genera (Hypoctonus, Typopeltis and Ginosigma) and several species of whip scorpions (Haupt, 1996), therefore it proves to be ideal for further studies on this group.

In general, the secretion products were collected from the spray (Eisner et al., 1961; Yogi and Haupt, 1977; Itokawa et al., 1981, 1985; Haupt et al., 1988, 1993). Schmidt et al. (2000) practiced another method: they shockfreezed the specimens, took off the opisthosomal gland and extruded the frozen secretion product directly from the frozen gland. Their object was again the American species Mastigoproctus giganteus.

If we compare the results of Schmidt et al. (2000) with those reported by Eisner et al. (1961), it is obvious that now many more ingredients were found. Such result may easily be attributed to the advance of analytical techniques during a period of almost forty years. Nevertheless, we also might have in mind some other aspects:

1) The opisthosomal gland is rather long, it may reach the anterior end of the opithosoma while its secretory ducts end in the metasoma. Schmidt et al. (2000) did not indicate from which region of the gland the samples were taken.

2) The secretion product inside the opisthosomal gland may be still in statu nascendi and quite different from the final spray.

3) The concentrations of the newly reported products are remarkably low. Therefore, the question remains, whether they practically play any role, at all. In general, an experienced chemist might even neglect such low concentrations or consider them either as unimportant artifacts and contaminations or as an reaction resulting from usually occurring products. Esters and ketones may easily result as reaction products from acids and alcohols. At present, there are no data available on the base of the same analytical procedure which might allow a comparison of the two different collecting methods. This certainly is a severe shortcoming and it has added significantly to the fact, that we used the traditional collecting method which allows comparison with data from literature more easily.

It is rather clear that the secrection product serves to repel potential enemies (Eisner et al., 1961) and that acetic acid plays a major role in it. Therefore, this ingredient was found in any case. This fact suggests that substances of lower concentrations may be more or less accidental and do not play any important role for the whip scorpion. This may be supported by the fact that these substances 
do not occur regularly but only in a smaller part of specimens once a larger number of one species could be tested (Table I). A major support for this opinion is the fact that concentrations of such additional substances vary to a great extent not only according to the stage of the whip scorpion but also to the conditions of repeated spraying.

While certain such substances may still have some repellent function, they may also play an entirely different role in other connections: Hexanol is known as an repellent of ants and cause health problems after inhalation, ingestion or skin absorption, but it is also added to perfumes to have better nuances. Hexyl acetate, its ester with acetic acid, is much more widespread in nature. Together with heptyl acetate it occurs in ripening bananas (Pelayo et al., 2003), and hexylacetate and octylacetate are present in strawberries (Aharoni et al., 2000). Heptanoic acid was found toxic for various vertebrates (Dawson et al., 1995). Octadecyl acetate is present in low concentrations in meat (Bouma and Douwes, 2002). Octanoic acid is a fre-

Aharoni A., Keizer L. C. P., Bouwmeester, H. J., Sun Z., Alvarez-Huerta M., Verhoeven H. A., Blaas J., van Houwelingen A. M. M. L., De Vos R. C. H., van der Voet H., Jansen R. C., Guis M., Mol J., Davis R. W., Schnena M., van Tunen A. J., and O'Connell A. P. (2000), Identification of the SAAT gene involved in strawberry flavor biogenesis by the use of DNA microarrays. Plant Cell 12, 647-662.

Bouma K. and Douwes B. A. (2002), Chemical Residues in Meat Nettings. Report Nr. ND 1 FC 003/01. Impectorate for Health Protection and Veterinary Public Health, Groningen, p. 25.

Dawson, D. A., Schutz, T. W., and Hunter R. S. (1995), Developmental toxicity of carboxylic acids to Xenopus embryos: A quantitative structure-activity relationship and computer-automated structure. Teratog. Carcinog. Mutagen. 16, 109-124.

Eisner T., Meinwald J., Monro A., and Ghent R. (1961), Defense mechanisms of arthropods. I. The composition and function of the spray of the whip scorpion, Mastigoproctus giganteus (Lucas). J. Insect Physiol. 6, $272-298$.

Haupt J. (1996), Revision of East Asian whip scorpions (Arachnida Uropygi Thelyphonida). II. Thailand and adjacent areas. Arthropoda Selecta 5, 53-65.

Haupt J. (2000), Biologie der Geißelskorpione (Uropygi Thelyphonida). Mem. Soc. entomol. ital. 78, 305-319.

Haupt J., Höhne G., Schwarz H., Chen B. S., Zhao W. B., and Zhang Y. C. (1988), Chinese whip scorpion using quent ingredient of perfumes and medicine apparently for its role in easing the access of other substances into the tissue. It is quite interesting that this substance is apparently absent or only present in very low concentrations in the species of the genus Hypoctonus. This fact may allow the conclusion, that this product is less effective when sprayed at potential enemies.

Thus, the variety and generally low concentrations of such substances in the secretion products of whip scorpions are certainly a hint of their insignificance and accidentalness, but various substances in low concentrations may also act as protection against microorganisms.

\section{Acknowledgements}

We are grateful to Mr. Sirichai Dinasiri (National Institute of Plant Protection, Bangkok) for supplying several whip scorpions, Prof. M. Hilker for fruitful discussions and DAAD, Bonn for financial support of the present work. 2-ketones in defense secretion (Arachnida: Uropygi). J. Comp. Physiol. B 157, 883-885.

Haupt J., Höhne G., and Weiske T. (1993), Acetic acid esters, $n$-hexanol, $n$-octanol, and capronic acid as ingredients in the defense secretion product of whip scorpions. C. R. XIVe Coll. Europ. Arachnol. Catania, 23-27 aout 1993. Boll. Acc. Gioenia Sci. Nat. 26, $175-180$.

Itokawa H., Kano R., Kaneko S., Nakajima T., Yasuhara T., and Yonabaru S. (1981), Chemical investigation of the spray of the Asian whip scorpion Typopeltis crucifer Pocock, 1894. Jpn. J. Sanit. Zool. 32, 67-71.

Itokawa H., Kano R., and Nakajima T. (1985), Chemical investigation of the spray of the Asian whip scorpion Typopeltis stimpsoni (Wood, 1862). Jpn. J. Sanit. Zool. 36, 65-66.

Pelayo C., Vilas-Boas E. V. de B., Benichou M., and Kadei A. A. (2003), Variability in responses of partially ripe bananas to 1-methylcyclopropene. Postharvest Biol. Technol. 28, 75-85.

Schmidt J. O., Dani F. R., Jones G. R., and Morgan E. D. (2000), Chemistry, ontogeny and role of the pygidial gland secretion of the vinegaroon Mastigoproctus giganteus (Arachnida: Uropygi). J. Insect Physiol. 46, $443-450$.

Yogi S. and Haupt J. (1977), Analyse des Wehrsekretes bei dem Geißelskorpion Typopeltis crucifer Pocock. Acta Arachnol. (Osaka) 27, 53-56. 